JIKSH: Jurnal Ilmiah Kesehatan Sandi Husada
https://akper-sandikarsa.e-journal.id/JIKSH
Volume 10| Nomor 1| Juni | 2021
e-ISSN: 2654-4563 dan p-ISSN: 2354-6093
DOI:https://doi.org/10.35816/jiskh.v10i1.492

\title{
Karakteristik Pasien Otitis Media Akut
}

\author{
Tan'im Arief ${ }^{1}$, Nia Triswanti ${ }^{2}$, Fatah Satya Wibawa ${ }^{3}$, Galang Aprianda Rulianta Adha ${ }^{4}$ \\ ${ }^{1234}$ Fakultas Kedokteran, Universitas Lampung
}

\begin{tabular}{|c|c|}
\hline Article Info & Abstraks \\
\hline $\begin{array}{l}\text { Article History: } \\
\text { Received:20-02-2021 } \\
\text { Reviewed:20-03-2021 } \\
\text { Revised:06-04-2021 } \\
\text { Accepted:22-05-2021 } \\
\text { Published:30-06-2021 }\end{array}$ & 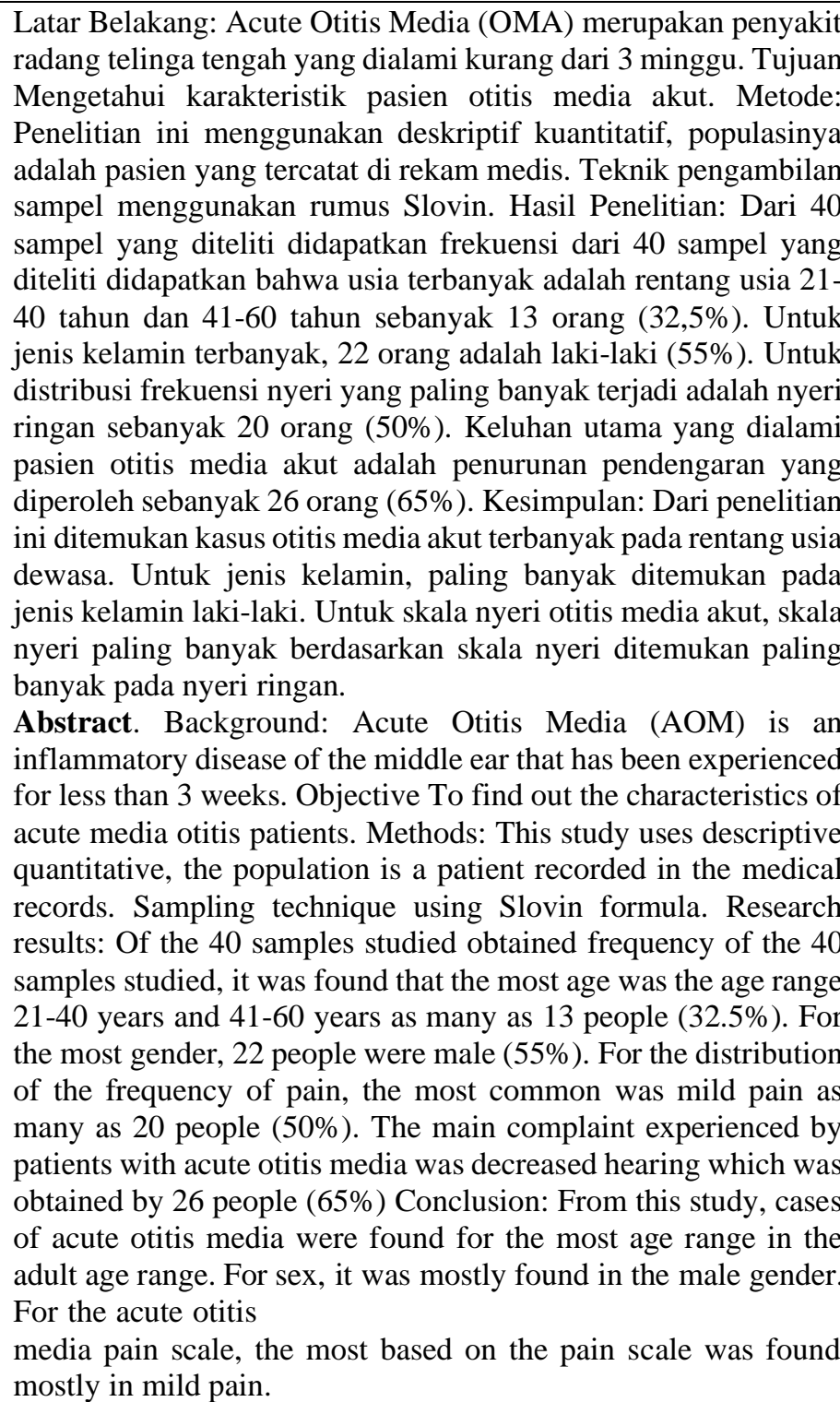 \\
\hline
\end{tabular}

\begin{tabular}{lll}
\hline Corresponding author & : Galang Aprianda Rulianta Adha & (W) \\
Email & galaprianda@gmail.com & $\begin{array}{c}\text { Chock for } \\
\text { updates }\end{array}$ \\
& About CrossMark \\
\hline
\end{tabular}


JIKSH: Jurnal Ilmiah Kesehatan Sandi Husada

Volume 10 Nomor 1 Juni 2021

\section{Pendahuluan}

Otitis Media Akut (OMA) merupakan peradangan pada telinga bagian tengah yang terjadi secara cepat dan singkat dalam waktu kurang dari 3 minggu disertai dengan gejala lokal seperti demam, nyeri, pendengaran berkurang, dan keluarnya cairan (Tesfa et.al, 2020). Otitis Media Akut disebabkan oleh bakteri dan virus yang paling sering ditemukan pada penderita OMA yaitu bakteri Streptococcus pneumaniae, diikuti oleh virus Haemophilus influenza (Buku Ajar Penyakit THT, 2015). Apabila penderita OMA kurang mendapatkan penanganan y ang adekuat maka akan mengalami komplikasi lanjutan yaitu Otitis Media Supuratif Kronik (OMSK) yaitu peradangan pada mukosa telinga tengah yang disertai keluarnya cairan melalui perforasi membran timpani selama lebih dari 2 bulan (Buku Ajar THT-KL, 2012).

Meskipun secara teoritis dinyatakan demikian, pendataan tentang kasus OMA berdasarkan tingkat usia menunjukkan hasil yang bervariasi pada berbagai negara. Kaneshiro menyatakan bahwa OMA merupakan penyakit yang umum terjadi pada bayi, balita, dan anakanak, sedangkan kasus OMA pada orang dewasa juga pernah dilaporkan terjadi, namun dengan frekuensi yang tidak setinggi pada anak-anak (Kaneshiro, 2010). Makin sering seseorang terserang ISPA, maka makin besar kemungkinan terjadinya OMA. Pada bayi dan anak terjadinya OMA diperolehh karena morfologi tuba eustachius yang pendek, lebar, dan letaknya agak horizontal, sistem imunitas tubuh masih dalam perkembangan serta adenoid pada anak relatif lebih besar dibanding orang dewasa dan sering terinfeksi sehingga infeksi bakteri maupun virus dapat menyebar ke telinga bagian tengah (Ghanie A, 2010).

Melihat peningkatan kasus Otitis Media Akut di berbagai negara termasuk di Indonesia yang menyerang populasi paling banyak adalah anak-anak, serta gejala dini yang seringkali dikenali dan menyebabkan penderita kebanyakan datang dengan keluhan mengganggu. Tujuan penelitian mengetahui tentang karakteristik pasien penderita otitis media akut yang dirawat atau berkunjung di Rumah Sakit Pertamina Bintang Amin Bandar Lampung.

\section{Metode}

Jenis penelitian ini adalah penelitian konsekutif deskriptif. Pengumpulan data dilaksanakan pada bulan Agustus tahun 2020. Tempat pengambilan sampel dilakukan di ruang rekam medik. Populasi penelitian ini adalah seluruh pasien di Poli THT yang mengalami Otitis Media Akut yaitu 63 pasien. Cara pengambilan sampel dalam peneltian ini adalah konsekutif sampling dengann teknik penentuan sampel berdasarkan menentukan pengambilan populasi dari peneliti menggunakan rumus slovin. $\mathrm{n}=\mathrm{N} /\left(1+\left(\mathrm{N} \mathrm{x} \mathrm{e}^{2}\right)\right) \cdot \mathrm{n}=63 /(1+(63 \times 0,052)) \cdot \mathrm{n}=40$ Sampel yang didapatkan yaitu berjumlah 40 pasien yang terdiagnosa mengalami Otitis Media Akut. Mengenai pengambilan sampel tersebut kemudian peneliti membaginya kedalam dua kriteria sampel yaitu inklusi (data yang dibutuhkan) dan eksklusi (data yang tidak lengkap). Kriteria inklusi adalah karakteristik umum subyek penelitian dari suatu populasi target yang terjangkau dan akan diteliti. Kriteria dalam penelitian yaitu data rekam medis lengkap dan data rekam medis diambil pada periode 2017-2019 Kriteria eksklusi dan eksklusi dalam penelitian ini adalah data rekam medis rusak/tidak terbaca dan data rekam medis tidak lengkap. Variabel dependen dalam penelitian ini, yaitu karakteristik. Variabel independen dalam penelitian ini, yaitu otitis media akut.

Teknik pengumpulan data pada usia, jenis kelamin, tingkatan nyeri dan keluhan utama adalah menggunakan data sekunder dengan cara observasi rekam medik kemudian didokumentasikan kedalam lembar observasi secara langsung oleh peneliti kemudian data langsung dikumpulkan hari itu. Prosedur pengolahan data yang sudah dikumpulkan yang akan 
di lakukan dalam penelitian ini ialah editing, koding, tabulasi, entry, cleaning. Analisis data dilakukan menggunakan program SPSS versi 22.0 dengan melakukan beberapa analisis data univariat dianalisis dengan menggunakan statistik deskriptif, yaitu persentase dan frekuensi pada variabel tergantung yaitu otitis media akut dan variabel bebas yaitu karakteristik.

\section{Hasil Dan Pembahasan}

Tabel 1.

Distribusi Frekuensi Usia

\begin{tabular}{|c|c|c|}
\hline Rentang Usia & Frekuensi & Persentase (\%) \\
\hline 1-20 Tahun & 12 & 30 \\
\hline 21-40 tahun & 13 & 32,5 \\
\hline 41-60 tahun & 13 & 32,5 \\
\hline 61-80 Tahun & 2 & 5 \\
\hline Total & 40 & 100 \\
\hline Jenis Kelamin & Frekuensi & Persentase $(\%)$ \\
\hline Laki-Laki & 22 & 55 \\
\hline Perempuan & 18 & 45 \\
\hline Total & 40 & 100 \\
\hline Skala Nyeri & Frekuensi & Persentase (\%) \\
\hline Tanpa Nyeri & 6 & 15 \\
\hline Ringan & 20 & 50 \\
\hline Sedang & 11 & 27,5 \\
\hline Berat & 3 & 7,5 \\
\hline Tak Tertahan & 0 & 0 \\
\hline Total & 40 & 100 \\
\hline Keluhan Utama & Frekuensi & Persentase (\%) \\
\hline Demam & 23 & 57,5 \\
\hline Berdengung & 24 & 60 \\
\hline Keluar Cairan & 22 & 55 \\
\hline Pendengaran Menurun & 26 & 65 \\
\hline Pusing & 7 & 17,5 \\
\hline Pusing & 11 & 27,5 \\
\hline
\end{tabular}

Sumber: data primer 2020 
Berdasarkan tabel, kelompok umur penderita otitis media akut yang tertinggi adalah pada rentang usia yaitu 21-40 tahun dan 41-60 tahun yaitu sama-sama sebanyak 13 orang (32,5\%). Kemudian diikuti kelompok umur 1-20 tahun sebanyak 12 orang (30\%). Sedangkan kelompok umur penderita otitis media akut yang terendah adalah pada rentang usia 61-80 tahun yaitu sebanyak 2 orang $(5 \%)$.

Jumlah penderita otitis media akut di Rumah Sakit Pertamina Bintang Amin Kota Bandar Lampung lebih banyak ditemukan pada laki-laki yaitu sebanyak 22 orang (55\%). Sedangkan pasien perempuan didapatkan sebanyak 18 orang (45\%). Skala nyeri yang paling sering dari pasien otitis media akut yaitu pada nyeri ringan yaitu sebanyak 20 orang (50\%), kemudian diikuti nyeri sedang yaitu sebanyak 11 orang $(27,5 \%)$ dan tanpa nyeri yaitu sebanyak

6 orang $(15 \%)$. Sedangkan didapatkan skala nyeri yang paling rendah yaitu nyeri berat didapatkan sebanyak 3 orang $(7,5 \%)$ dan tidak ditemukannya nyeri tak tertahan yaitu 0 pasien $(0 \%)$. Keluhan utama yang paling banyak dialami dari pasien otitis media akut yaitu pendengaran menurun didapatkan sebanyak 26 orang (65\%), kemudian diikuti berdengung yaitu sebanyak 24 orang (60\%), kemudian demam sebanyak 23 orang $(57,5 \%)$, kemudian keluar cairan sebanyak 22 orang (55\%), dan hidung tersumbat sebanyak 11 orang $(27,5 \%)$. Sedangkan keluhan utama yang paling sedikit dialami yaitu pusing sebanyak 7 orang $(17,5 \%)$.

Menurut hasil penelitian (Amelia, 2020) menyatakan bahwa bakteri penyebab otitis media supuratif kronik (OMSK) terbanyak adalah Pseudomonas sp dan Staphylococcus. Otitis media akut paling sering terjadi pada kelompok toddlers, anak dengan jenis kelamin laki-laki, anak dengan pekerjaan orang tua ibu rumah tangga (Kardinan \& Dani, 2014). Menurut (Putra \& Saputra, 2013) bahwa keluhan terbanyak yang dialami oleh penderita otitis media supuratif kronis adalah telinga berair (otorhea) kemudian diikuti oleh gangguan pendengaran. (Praptika \& Sudipta, 2020) berpendapat bahwa karakteristik utama dari pasien OMA pada kelompok umur 011 tahun, berjenis kelamin perempuan, pada fase hiperemi dan mengenai telinga kanan unilateral.

\section{Simpulan Dan Saran}

Bahwa semakin tinggi tingkat pengetahuan yang baik maka akan membentuk perilaku yang baik pula. Perlu dilakukan penelitian lebih luas cakupan faktor yang mempengaruhi otitis media akut dapat menjadi suatu pertimbangan untuk perencanaan program. Pemerintah harus memberikan informasi mengenai deteksi dini, khususnya otitis media akut kepada masyarakat secara luas untuk peningkatan pelayanan mutu pelayanan kesehatan seperti melakukan tindakan preventif dan kuratif untuk menangani otitis media akut di masyarakat.

\section{Daftar Rujukan}

Amelia, M. (2020). Identifikasi Mikroorganisme Penyebab Otitis Media Supuratif Kronik Dan Kepekaannya Terhadap Antibiotik. JIKSH: Jurnal Ilmiah Kesehatan Sandi Husada, 9(1 SEArticles). https://doi.org/10.35816/jiskh.v11i1.351

Evan, R. M. (2010). Pathophysiology of Pain and Pain Assesment. American Medical Association, 1-12.

Ghanie, A. (2010). Penatalaksanaan Otitis Media Akut Pada Anak.

Glasper, E. A., McEwing, G., \& Richardson, J. (Eds.). (2011). Emergencies in children's and young people's nursing. OUP Oxford. 
Ilmyasri, S. A. (2020). Diagnosis and Management of Acute Otitis Media. Jurnal Penelitian Perawat Profesional, 2(4), 473-482.

Irawati, L. (2012). Fisika Medik Proses Pendengaran. Majalah Kedokteran Andalas, 36(2),

Kardinan, S. S. B., \& Dani, S. S. (2014). Karakteristik Pasien Rawat Inap Otitis Media Akut Di Rumah Sakit Immanuel Bandung Periode Januari-Desember 2013. Skripsi, Fakultas Kedokteran, Universitas Kristen Maranatha.

Korompis, A. M., Tumbel, R. E. C., \& Mengko, S. K. (2018). Kesehatan Telinga di Sekolah Dasar Negeri 11 Manado. e-CliniC, 6(1). 155-162.

Lestari, N. E., \& Herliana, I. (2020). Implementasi Pendidikan Seksual Sejak Dini Melalui Audio Visual. Jurnal Pengabdian Masyarakat Indonesia Maju, 1(01), 29-33.

Mahardika, I. W. P., Sudipta, I. M., \& Sutanegara, S. W. D. Karakteristik Pasien Otitis Media Akut Di Rumah Sakit Umum Pusat Sanglah Denpasar Periode Januari-Desember Tahun 2014.

Nazarudin, N. Otitis Media Akut Dengan Komplikasi Mastoiditis Akut Dan Labirintitis Akut Pada Dewasa (Acute Otitis Media with Complications of Acute Mastoiditis And Acute Labyrinthitis In Adult).

Putra, A. A. B. R. D. A., \& Saputra, K. A. D. (2013). Karakteristik Pasien Otitis Media Supuratif Kronis Di Poliklinik Tht Rumah Sakit Umum Pusat Sanglah Periode Januari - Juni 2013. E-Jurnal Medika Udayana; Vol 5, No 12 (2016): E-Jurnal Medika Udayana. https://ocs.unud.ac.id/index.php/eum/article/view/26635

Perry, P., \& Potter Patricia, A. (2010). Fundamental Keperawatan: Konsep, Proses, Dan Praktik. Jakarta: EGC.

Praptika, N. L. P., \& Sudipta, I. M. Karakteristik Kasus Otitis Media Akut Di Rsud Wangaya Denpasar Periode November 2015-November 2016. E-Jurnal Medika Udayana, 9(8), 4752.

Rosyidah, N. (2018). Uji Diagnostik Otoendoskop Dibandingkan dengan Otoskop Langsung dalam Mendiagnosis Kelainan Telinga Pada Usia 60 tahun Keatas di Panti Berdikari BSD dan Panti Werdha Melania Rempoa. 2018 (Bachelor's thesis, UIN Syarif Hidayatullah Jakarta-FK).

Simbolon, A. Y. P. A. (2019). Prevalensi Otitis Media Akut di Provinsi Sumatera Utara.

Soepardi, E. A., Iskandar, N., Bashiruddin, J., \& Restuti, R. D. (2017). Buku ajar ilmu kesehatan telinga hidung tenggorok kepala \& leher. Jakarta: Balai Penerbit FK UI, 221.

Tesfa, T., Mitiku, H., Sisay, M., Weldegebreal, F., Ataro, Z., Motbaynor, B., ... \& Teklemariam, Z. (2020). Bacterial otitis media in sub-Saharan Africa: a systematic review and metaanalysis. BMC Infectious Diseases, 20(1), 1-12.

Utomo, B. S., \& Siregar, F. F. (2018). Profil Klinis Otitis Media Akut di Rumah Sakit Umum Universitas Kristen Indonesia. Majalah Kedokteran, 34(1), 41-43 